\title{
REAL OPTIONS, INVESTMENT AND FINANCING DECISIONS, AND THE THEORY OF THE FIRM
}

\author{
Asım Gürsel ÇRLtx*
}

\section{INTRODUCTION}

In the agency theory of the firm, Jensen and Mackling (1976) defines the corporations as legal fictions which serve as a nexus for a set of contracting relationships among individuals. ${ }^{1}$ The agency costs explanation of the theory of the firm helps us to understand better the nature of the relationships among owners, managers, debcholders, employees, suppliers, costumers and the regulatory power.

In another seminal paper, Black and Scholes (1973) provides a key to the valuation of contingent claims which, like options, have payoffs that are contingent on the future value of another asset. They not only enhance our understanding of financial investments but also show that if the firm's cash flow distribution is fixed, the option pricing analysis can be used to value other contingent claims such as the equity of a levered firm. In this context, the equity of a levered firm is a call option on the total value of the firm's assets with an exercise price equal to the face value of the debt and the expiration date equal to the maturity date of the debt.

More recently, financial economists have come to view investment opportunities as real options, exploiting an analogy with the theory of options in financial markets. ${ }^{2}$ These developments in corporate finance lead us to consider the firm as a nexus for a set of options contracts among individuals.

\footnotetext{
*Ph. D. student, Department of Finance, The University of Texas at Arlington, Box 19449 Business Bldg., Arlington, Texas 76019, U.S.A.

${ }^{1}$ The antecedents of their work are in Coase (1937) and Alchian and Demsetz (1972).

2 For an excellent exposition to the subject see Dixit and Pindyck (1994). Triegorgis (1993) also provides a complete review of the real options literature. For several applications see Laughton and Jacoby (1933), Smit and Ankum (1993), Kasanen (1993), Kemna (1993), Kulatilaka (1993), Pindyck (1993), Cortazar and Schwartz (1993), Trigeorgis (1993 b), Kogut (1991), Hubbard (1994), Myers and Majd (1985), and Mason and Baldwin (1988).
} 
The purpose of this paper is to investigate the possible effects of real options on firm's investment and financing decisions. The paper consists of four sections. Following introluction, section two discusses real options that embeded in investment decisions and provides a numerical example for valuing real options. Section three attempts to explain the effects of real options on firm's investment and financing decisions. This section also outlines a model for firm valuation in contingent claim analysis framework. Section four concludes.

\section{REAL OPTIONS}

Net Present Value (NPV) and other discounted cash flow (DCF) approaches to capital budgeting are incomplete in the sense that they cannot properly capture managerial flexibility. In practice, however, as new information arrives and uncertainty about market conditions and future cash flows is gradually resolved, management may have valuable flexibility to alter its operating stratesy in order to capitalize on favorable future opportunities or mitigate losses. For example, management may be able to defer, expand, contract, abandon, or otherwise alter a project at different stages during its useful operating life.

Management's flexibility to adapt its future actions in response to altered future market conditions expands an investment opportunity's value by improving its upside potential while limiting downside losses relative to management's initial expectations under: passive management.

An options approach to capital budgeting has the potential to conceptualize and even quantify the value of options from active management. This value is manifest as a collection of real options embedded in capital investment opportunities, having as an underlying asset the gross project value of expected operating cash flows. Many of these real options occur naturally (e.g., to defer, contract, shut down or abandon), while others may be planned and built-in at some extra cost (e.g., to expand capacity or built growth options, to default when investment is staged sequentially, or to switch between alternative inputs or outputs) (Trigeorgis, 1993).

The option to defer investment is analogous to an American call option on the gross present value of the completed project's expected operating cash flows, $V$, with the exercise price of the required outlay, $I$. Thus, it's value will be $\max (V-I, O)$.

The option to default during construction (or the time-to-build option) can be valued similar to compound options approach of Geske (1979). The actual staging of capital investment as a series of outlays over time creates valuable options to "default" at any given stage. Thus, each stage is an option on the value of subsequent stages with exercise price of the installment cost outlay required to proceed to the next stage.

The option to expand is a call option to acquire an additional part (x \%) of the trase scale project, with a value of $\max \left(x V-I_{E}, O\right)$, where $x$ is percentage rate of expansion and $\mathrm{I}_{\mathrm{E}}$ is the expansion outlay. 
The option to contract is a put option and reflects management's flexibility to operate below capacity or even reduce the scale of operations, thereby saving part of the planned investment outlays. The value of this option is $\max (\mathrm{IC}-\mathrm{cV}, \mathrm{O})$, where $\mathrm{c}$ is the percentage rate of reduction in the scale of operations and $I_{C}$ is the associated cost saving.

The option to shut down (and restart) operations is a call option to acquire a paticular year's cash revenues (C) by paying the variable operating cost (IV) as exercise price, i.e., $\max (C-I V, O)$.

Options to alter the operating scale (i.e., expand, contract, or shut down) are typically found in natural resource industries, such as oil and mine operations, facilities planning and construction in cyclical industries, fashion apparel, consumer goods, and commercial real estate.

The option to abandon for salvage value is an American put option on current project value (V) with exercise price the salvage or best altemative use value (A), i.e., $\max (A-V, O)$. Valuable abandonment options are generally found in capital intensive industries, such as airlines and railroads, in financial services, as well as in new product introductions in uncertain markets.

The option to switch use (i.e., inputs or outputs) is a valuable builtin flexibility to switch from the current input to the cheapest future input, or from the current output to the most profitable future product mix, as the relative prices of the inputs or outputs fluctuate over time. Input flexibility is valuable in feedstock-dependent facilities, such as oil, electric power, chemicals, and crop switching. Output flexibility is more valuable in industries such as automobile, consumer electronics, toys or pharmaceuticals, where product differentiation and diversity are important and/or product demand is volatile.

Corporate growth options: Many early investments such as research and development, a lease on undeveloped land or a tract with a potential oil reserves, a strategic acquisition, or an information technology network are prerequisites $\alpha$ links in a chain of interrelated projects. The value of these projects may derive not so much from their expected direculy measurable cash flows, but rather from unlocking future growth opportunities. An opportunity to invest in a first-generation high tech product, for example, is analogous to an option on options (an interproject compound option). Growth options are found in all infrastructure based or strategic industries, especially in high-tech, R\&D, or industries with multiple product generations or applications (e.g.. semiconductors, computers, pharmaceuticals), in multinational operations, and strategic acquisitions.

\section{Valuing Real Options: An Example}

Consider an oil extraction project with extraction cost 208 million. Today's oil price is $\mathbf{4 0}$ dollar per barrel and the oil field has a capacity of 5 million barrel per year for two years. We expect oil price to go either up to 21 ( 80 percent) or down to 24 (40 percent). Risk free rate is 8 percent. 


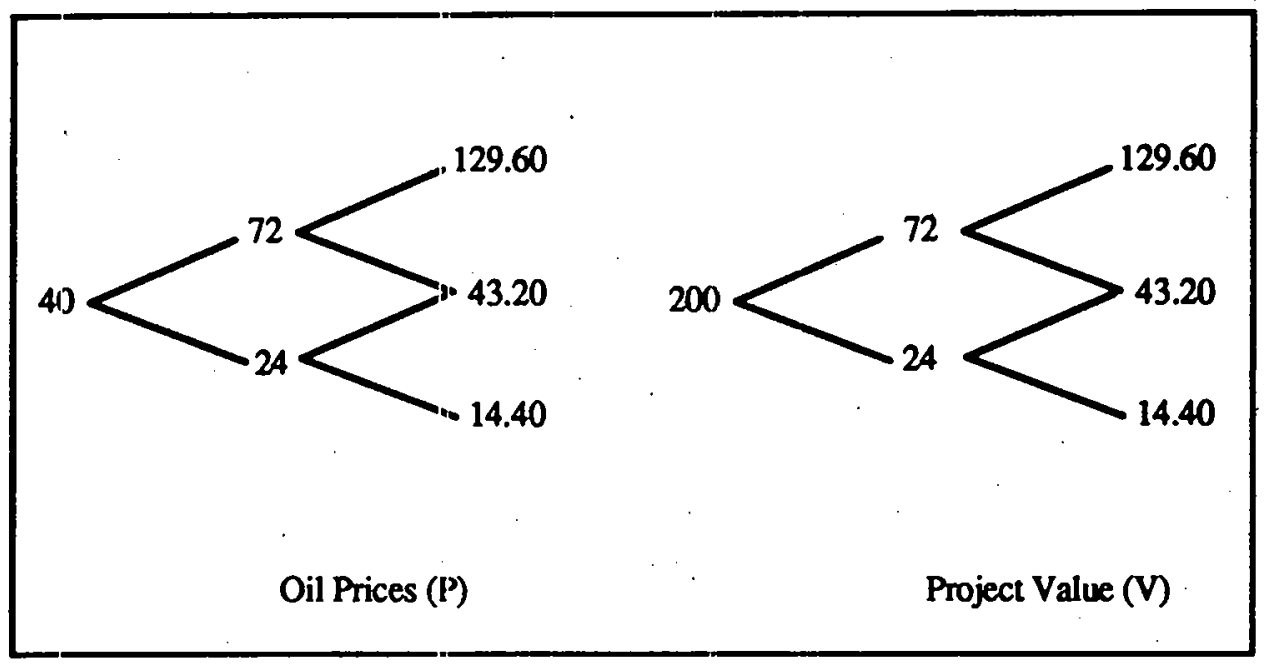

Figure 1: Binomial trees for oil prices and project value.

The NPV of this project: is $(200-208=)-8<0$, and DCF analysis results in the rejection of the project. DCF analysis, however, ignores at least one option embedded in this project, the option to abandon the oil extraction at any time in exchange for its sal vage value or value in its best altemative use if oil prices suffer a substantial decline. Assume that its best alterntive use is land development. Land development has a value of 180 million which is below the project's value in its present use-otherwise management would have to abandon the project immediately. We believe that the value of the land development will go up 60 percent or down 20 percent.

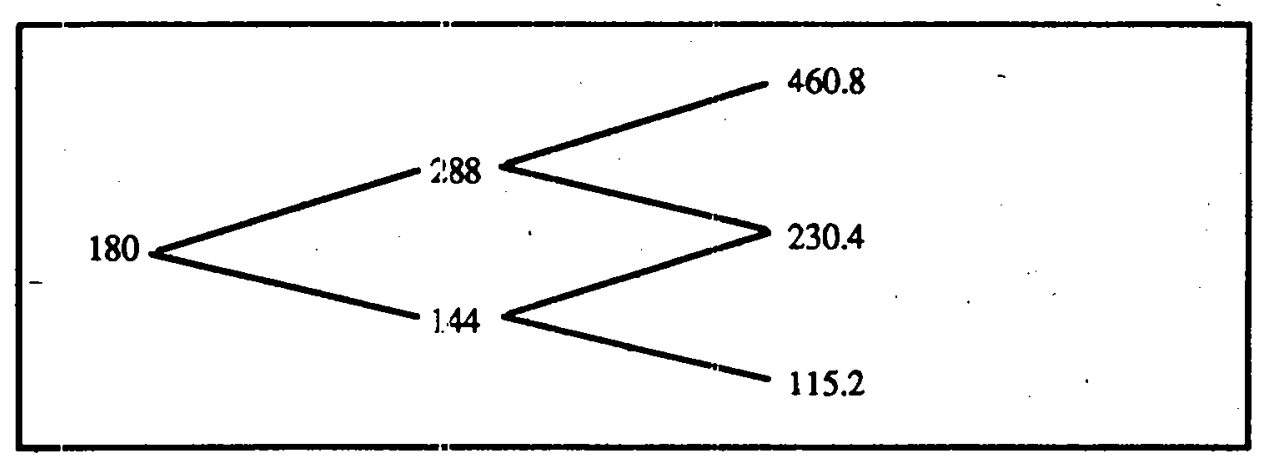

Figure 2: Binomial tree for the value of land development.

This abandonment value is an American put option on current project value (V) with exercise price the land development value $(A)$. This option entitles management to receive additional cash flow of $\max (A-V, O)$. 


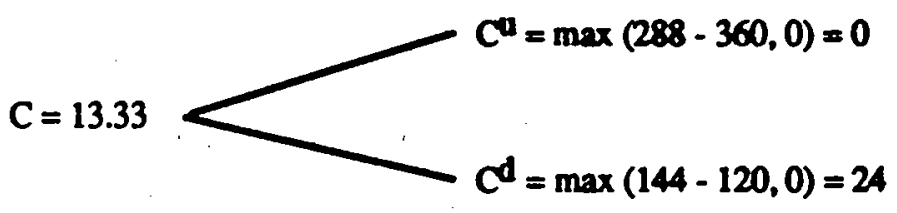

Figure 3: Payoff structure of the abandonment option.

Value of this option by using rist-neutral binomial option pricing formule ${ }^{3}$ is 13.33. Thus, the NPV of the project with option will be $(13.33-8=5.33$ million.

This example supports McDonald and Siegel (1986)'s assertion that the simple net present value rule which is to invest as long as $\mathrm{V}>\mathrm{I}$ is incorrect. This rule is incorrect because it ignores the opportunity cost of making a commitment now, and thereby giving up the option of waiting for new information.

\section{REAL OPTIONS AND INTERACTIONS BETWEEN FINANCING AND INVESTMENT DECISIONS.}

Myers (1977) is the first to explain the relation between financing and investment decisions in a contingent claim framework. He describes the firm's potential investment opportunities as call options whose value depend on the likelihood that management will exercise them. If the firm has risky debt outstanding, situations arise in which exercising the option to undertake a positive net present value project potentially reduces share value because debtholders have a senior claim on the project's cash flows. Unless this conflict between the shareholders and debtholders is controlled, the probability that these real investment options will be exercised is reduced, thereby reducing firm value. One way to control this underinvestment problem and its associated value loss is to finance growth options with equity rather than debt (Smith and Watts, 1992). Hence Myers predicts that the larger the proportion of firm value represented by growth options (i.e., the lower the assets in place), the lower the firm's leverage, and the higher its equity-to-value ratio.

Hite (1977) presents a model in which he combines seemingly distinct theory of production and output, the theory investment and the theory of financial policy toward an integrated theory of the firm. His model is based upon discrete-time, continuous space variables. In other words he uses single-period CAPM with continuous demand and production functions. His model is static and does not consider the real options that a firm might have. The model presented here extends his model by using continuous-time, continuous space variables (i.e., continuous-time capital asset pricing model of Merton (1973) or Breeden (1979)). In addition our model incorporates various real options to reflect managerial flexibility in production, investment, and financing docisions.

${ }^{3} \mathrm{C}=\left[\mathrm{p} \mathrm{C}^{\mathrm{u}}+(1-\mathrm{p}) \mathrm{C}^{\mathrm{d}}\right] /(1+\mathrm{r})$ where $\mathrm{C}$ is call option price; $\mathrm{p}$ is risk-neutral probability (.4); and $u$ and $d$ refers to up and down states, respectively $\left(C^{u}=0, C^{d}=24 \lambda, \mathrm{r}\right.$ is rist-free race $(.08)$.

The risk-neutral probability is calculated by using: $p=\left[(1+r) P \cdot p^{d}\right] /\left(p^{*}-p^{d}\right)$. $P$ in price of the oil $\left(P=40, p^{u}=72, p^{d}=24\right.$, and $\left.p=0.4\right)$. 


\section{The Model:}

Assume that the project value (cash flow) evolves according to the following geometric brownian motion: 4

$$
d V=a V d t+s V \cdot d z
$$

where $\mathrm{dz}$ is increment of a Wiener process, $\mathrm{a}$ is the drift rate, and $\mathrm{s}$ is instantaneous volatility per unit of time. Equation (1) implies that the current value of the project is known, but future values are lognormally distributed with a variance that grows linearly with the time horizon. Thus although information arrivies over time (the firm observes $V$ changing), the future value of the project is always uncertain.

Our goal is to maximizs: the value of the investment opportunity, $F(V)$ (that is, the value of the option to invesl:-

$$
F(V)=\max E\left[\left(V_{T}-I\right) e^{-q T}\right]
$$

where $\mathrm{E}$ denotes the expectation, $\mathrm{T}$ is the (unknown) future time that the investment is made, $q$ is a discount rate, and the maximization is subject to equation (1) for $V$.

Assume that stochastic changes in $\mathrm{V}$ are spanned by the existing assets in the economy. This assumption will let us to make use of contingent claim analysis.

Let $\mathrm{x}$ be the price of an asset or dynamic portfolio of assets perfectly correlated with $V$. Since $x$ is perfectly correlated with $V$, $\operatorname{cor}(x, M)=\operatorname{cor}(V, M)$ where $M$ is the market portfolio. We will assume that this asset or portfolio pays no dividends, so its entine return is from capital gairs. Then $x$ evolves acconding to

$$
d x=m x d t+s x d z
$$

where $m$, the drift rate is the explected rate of return from holding this asset or portfolio of assets. According to CAPM, m should reflect the asset's systematic (nondiversifiable) risk. ${ }^{5} \mathrm{~m}$ will be given by

$$
\mathbf{m}=\mathbf{r}+\emptyset \operatorname{corr}(\mathbf{x}, \mathrm{M}) \mathrm{s}
$$

\footnotetext{
${ }^{4}$ This is a simplistic assumptioi. More realistically, one might argue that project value follow some different stochastic: process. For example, one might believe that over long periods of time, oil prices (and the prices of other commodities) are drawn back towards long-run marginal cost, and thus are mean reverting.

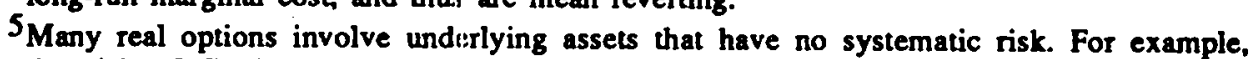
the risk of finding oil in an exploratory well is unsystematic, as is the research a development risk. Moreover, when the underlying asset has no systematic risk, the risk neutral probability is the same is the true probability (Sick, 1990).
} 
where $r$ is the risk-free interest rate, and $\varnothing$ is the market price of the risk. 6 Thus $m$ is the risk adjusted expected rate of return that investors would require if they are to own the project.

Now, consider the following portfolio: Hold the option to invest, which is worth $F(V)$, and go short $n=F(V)$ units of the project (or, equivalently, of the asset $a$ portfolio $x$ that is perfectly correlated with $V$ ). The value of this portfolio is

$$
Q=F \cdot F(V) V
$$

and its value is obtained by solving the fundamental equation of asset valuation:

$$
1 / 2 s^{2} V^{2} F^{n}(V)+(r-k) V F(V)-r F=0
$$

where, $k=m-a$ and the boundary conditions are:

$$
\begin{aligned}
& F(0)=0 \\
& F\left(V^{*}\right)=V^{*}-I \\
& F^{*}\left(V^{*}\right)=1
\end{aligned}
$$

Condition (6) arises from the observation that if $\mathrm{V}$ goes to zero, it will stay at zero (i.c., bankruptcy). $V^{*}$ is the price at which it is optimal to invest. Equation (7) just says that upon investing, the firm receives a net payoff $V^{*}-I$. The condition (8) is the smoothpasting condition.

An example of this model is oil extraction project where $V$ is the value of this project and $x$ is the oil price per barrel. We can apply this approach to Hite's model by defining $\mathrm{V}$ as firm value and $\mathrm{x}$ as net (net of operating costs) cash flows. .

So far we have explained how to apply contingent claim analysis to valuation of the firm. However, our main goal is to incorporate real options to this valuation, since it substantially affects the value of the firm and the risk adjusted required rate of retum. Assume that operation of the firm will temporarily and costlessly suspended when cash flows (x) falls below a flow cost (c). Therefore at any instant the net cash flow from this project is given by

$$
y(x)=\max (x-c, 0)
$$

With this real option firm value satisfies the differential equation in (5) plus $y(x)$.

The solution to this model can be oblained by using stochastic calculus. With the inclusion of multiple real and financial options, however, it is not an easy task if not possible. In such an attempt Mauer and Triantis (1994) uses numerical solution techniques:

${ }^{6}$ That is, $\emptyset=\left(r_{M}-r\right) / s_{M}$. where $r_{M}$ is the expected return on the market, and $s_{M}$ is the standard deviation of market return. 
Mauer and Triantis analyze the interaction between investment and financing decisions in a multiperiod contingent claims model where the firms has flexibility to dynamically manage both decisions over time. They find that production flexibility has a positive effect on the value of interest tax shields. The ability to shut down operations allow the firm to mitigate operating losses. Therefore, as operating adjustment costs decrease, firm value increases and firm value variance decreases, increasing the debt capacity of the firm and the associated net benefit of interest tax shields. However, production flexibility and financial flexibility are to some degree substitutes, since the effect of lower operating adjustinent costs on net tax shield value is less pronounced the smaller are recapitalization costs. They also examine the effect of production flexibility on the firm's optimal dynamic recapitalization policy. As operating adjustment costs decriase, the average leverage ritio increases and the range over which the firm allows its optimal leverage ratio to vary without recapitalizing decleases.

In contrast, they find that debt financing has at negligible impact on the firm's investment and operating policies. This is also a contradiction to Hite's first proposition that the financing policy carnot be ignored in choosing the optimal productive technique. ${ }^{7}$ For example, while a levered firm has in incentive to invest earlier (i.e., at a lower commodity price) than an equivalent unlevered firm because it eams interest tax shields when it is operating, the benefit from doing so is largely offset by a loss in the value of waiting to invest. Therefore, the net benefit: is not large enough to effect a significant change in investment policy. Similarly, their analysis indicates that any additional interest tax shields that a levered firm can earn by deviating from the optimal operating policy of an equivalent unlevered firm are counterbalanced by a loss in the value of its operating options. Thus a levered firm has little incentive to alter operating policy. From a practical standpoint, the implication is that the firm can determine exercise timing decisions on its real options, ignoring the effect of debt financing. However, since their results are numerical rather than analytic, they depend on the choice of parameter inputs.

\section{CONCLUSION}

This paper investigates the role of real options in 'capital budgeting, investment, and financing decisions. The net present value or other discounted cash flow approaches to capital budgeting fail to reflict real option values in capital budgeting decisions and therefore may lead to wrong decisions in acceptance or rejection of the project.

Real options in the form of production flexibility has a significant effect on financing decisions. In contrast, financial policy has a minimal effect on the firm's initial investment decision and subsequent operating. However these results are sensitive to choice variables.

Real options approach is rich in real-life applications and fruitful in future research. Extending it, for exiample, by using Bayesian analysis or altemative (e.g., jump) processes is only one among many directions for research.

7 In general, a firm that employ; at least some leverage will not employ the same capitallabor ratio that would be optimal if the firm were unlevered. 


\section{REFERENCES}

Alchian, Armen A., and Herold Demsetz, 1972, Production, information costs, and economic organization, American Economic Review 62 (5), 777-795.

Breeden, Douglas T., 1979, An intertemporal asset pricing model with stochastic consumption and investment oportunities, Joumal of Financial Economics 7, 265-96.

Black, Fisher, and Myron Scholes, 1973, The princing of options and corporate liabilities, Joumal of Political Economy 81, 637-659.

Coase, Ronald H, 1937, The nature of the firm, Economica 4, 386-405.

Cortazar, Gonzalo and Eduardo S. Schwartz, 1993, A compound option model of production and intermediate inventories, Journal of Business 66 (4), 517-24.

Geske, Robert, 1979, The valuation of compound options, Journal of Financial Economics 7, 63-81.

Hite, Gailen L., 1977, Leverage, output effects, and the M-M theorems, Journal of Financial Economics (4) 2, 177-202.

Hubbard, R. Gleen, 1994, Investment under uncertainty: keeping one's options open, Journal of Economic Literature 32 (4), 1816-1831.

Jensen, Michael C., and William H. Meckling, Theory of the firm: Management behavior, agency costs and ownership structure, Journal of Financial Economics 3, 305-360.

Kasanen, Eero, 1993, Creating value by spawning investment opportunities, Financial Management 22 (3), 251-258.

Kemna, Angelien G. Z., 1993, Case studies on real options, Financial Management 22 (3), 259-270.

Kogut, Bruce, 1991, Joint ventures and the option to expand and acquire, Management Science 37 (1), 19-33.

Kulatilaka, Nalin, 1993. The value of flexibility: the case of a dual-fuel industrial steam boiler, Financial Management 22 (3), 271-280.

Laughton, David G., and Henry D. Jacoby, 1993, Reversion, timing options, and longterm decision-making, Financial Mangement 22 (3), 225-240.

Mason, Scott P., and Carliss Y. Baldwin, 1988, Evaluation of government subsidies to large-scale projects: a contingent claims pproach, Advances in Futures and Operations Research 3, 169-181. 
Mauer, David C., and Alexandor J. Triantis, 1994, Interactions of corporate financing and investment decisions: a dynamic framework., Journal of Finance 49 (4), 12531277.

McDonald, Robert and Daniel R. Siegel, 1985, Investment and the valuation of firms when there is an option to shut down, International Economic Review 26 (2), 331-349.

Merton, Robert C., 1973, An intertemporal capital asset pricing model, Econometrica 41, 867-880.

Myers, Stewart C., and Saman Majd, 1985, Calculating abandonment value using option princing theory, Slcaan school working paper \# 1462-83, M. I. T.

Myers, Stewart C., 1977, Determinants of corporate: borrowing, Journal of Financial Economics 5, 147-175.

Pindyck, Robert S., 1993, Investments of uncertain cost, Journal of Financial Economics 34 (1), \$3-76.

Quigg, Laura, 1993, Empirical testing of real option-princing models, Journal of Finance $48(2), 621-640$.

Sick, Gordon, 1990, Capital budgeting with real options, Monograph 1989-3, Salomon Brothers Center for the Study of Financial Institutions, New York University.

Smit, Han T. J., and L. A. Anlium, 1993, A real options and game-theoretic approach to corporate investmelit strategy under competition, Financial Management 22 (3), 241-250.

Smith, Clifford W., and Ross L. Watts, The investment opportunity set and corporate financing, dividend, and compensation policies, Journal of Financial Economics 32, 263.292.

Trigeorgis, Lenas, 1993a, Real options and interactions with financial flexibility, Financial Management 22 (3), 202-224.

, 1993b, The natur: of option interactions and the valuation of investments with multiple real options, Journal of Financial and Quantitative Analysis 28 (1), 1-20. 